Article available at http://www.parasite-journal.org or http://dx.doi.org/10.1051/parasite/2002093225

\title{
Gymnomeropsylla n. gen. (Siphonaptera: Pygiopsyluidae) FROM SULAWESI, INDONESIA, WITH THE DESCRIPTION OF TWO NEW SPECIES
}

\author{
DURDEN L.A.* \& BEAUCOURNU J.C.**
}

\section{Summary:}

Compared to related genera, this new flea genus is characterized by the absence, or presence of very few, bristles on the external surface of femur I and especially by the morphology of the apex of sternite IX in the male, which is hyaline and lacks spiniform bristles. The two new species, $G$. bunomydis and

G. margaretamydis, are distinguished from each other by the structure of the genitalia, and the presence of numerous erect bristles on the thorax and abdominal tergites of the latter species. Both of these new species parasitize murine rodents that are endemic to Sulawesi; $G$. bunomydis was collected mainly from Bunomys chrysocomus and $G$. margaretamydis only from Margaretamys parvus.

KEY WORDS : Gymnomeropsylla n. gen., G. bunomydis n. sp. G. margaretamydis n. sp., fleas, Siphonaptera, Pygiopsyllidae, Sulawesi, Indonesia.

\section{INTRODUCTION}

$\mathrm{D}$ urden \& Traub (1990) reported two new genera of pygiopsyllid fleas from Sulawesi and designated them as "New Genus 1" and "New Genus 2", respectively, with the latter genus including two undescribed species. It is the latter of these genera that we have studied and described here. Traub (1972b) suggested that the Wallacean subregion, consisting of Mindanao, Sulawesi (Celebes), Timor and the small islands of the Sundaic "zone", was isolated. Later, Traub et al. (1983) elevated these islands (Timor, Sulawesi, Flores, Sumba, etc.) to the rank of region. This latter viewpoint was treated cautiously in a reevaluation by Lekagul (1988) and was not followed by Beaucournu et al. (2000) but was conserved by Durden \& Traub (1990). This distinction between region and subregion will not be further discussed here. However, within the Wallacean realm, the large island of Sula-

\footnotetext{
* Institute of Arthropodology \& Parasitology, Georgia Southern University. P.O. Box 8056, Statesboro, Georgia 30460, USA. Tel.: 912 681-0553 - Fax: 912-681-0559.

E-mail: ldurden@gsvms2.cc.gasou.edu

** Laboratoire de Parasitologie et Zoologie appliquée, Faculté de Médecine, Université de Rennes 1, 2, avenue du Pr Léon Bernard, 35043 Rennes cedex, France. Tél.: $33(0) 223234643$ - Fax: $33(0) 223234629$. E-mail: jbeaucou@univ-rennes1.fr

Correspondence: Lance Durden.
}

Résumé : Gymnomeropsylla N. Gen. (Siphonaptera: PygiopsyllidaE) Du Sulawesi, Indonésie, aVec Description de Deux espèces NOUVELLES

Ce nouveau genre est, entre autres, caractérisé par l'absence ou le très faible nombre de soies sur la face externe du fémur $\mathrm{I}$, et surtout la structure de l'apex du sternite IX, hyalin et dépourvu de toutes soies spiniformes. Les deux espèces nouvelles,

$G$. bunomydis et $G$. margaretamydis se distinguent entre elles par les genitalia et la présence de très nombreuses soies dressées sur le thorax et les tergites abdominaux chez la seconde. Ces deux espèces parasitent les rongeurs murinés endemiques du Sulawesi; $G$. bunomydis essentiellement sur Bunomys chrysocomus et G. margaretamydis sur Margaretamys parvus seulement.

MOTS CLÉS : Gymnomeropsylla n. gen., G. bunomydis n. sp., G margaretamydis n. sp., puces, Siphonaptera, Pygiopsyllidae, Sulawesi, Indonésie.

wesi is particularly rich in endemic taxa of various groups of animals and plants. Therefore, we are not surprised that an undescribed flea genus has been collected on Sulawesi.

\section{Gymameropsylla Durden \& Beaucournu, N. GEN.}

Material examined: see species descriptions.

This new genus would be placed in the subfamily Pygiopsyllinae (sensu Smit, 1987) and, in a more restrictive interpretation, in the subfamily Stivaliinae (sensu Mardon, 1981). We have followed the latter contribution because it represents the latest revision of the family. The subfamily Stivaliinae includes 23 genera according to Mardon (1981), or 24 according to Lewis (1998) who conserved Aviostivalius as a distinct genus; members of this genus were integrated into the genus Lentistivalius by Mardon (1981). Nevertheless, it appears to us that the boundary between the Pygiopsyllinae and Stivaliinae is subtle and does not seem to represent a major phylogenetic distinction within the Pygiopsyllidae. As a supplementary argument in support of this statement, the tentorial arch is considered to be absent in all members of the Stivaliinae, and present or absent in members of the Pygiopsyllinae. In one of the specimens we examined, this structure is perfectly developed 


\section{DESCRIPTION}

Head (Fig. 1). Tentorial arch normally absent. Eye with more or less clear ventral sinus, fused on its dorsal border to the postgena, situated above the apex of coxa I. Head capsule rounded, lacking frontal tubercle and without modified bristles. Prothoracic ctenidium present. Femur I with 0-3 bristles on external lateromedial surface. Antesensilial bristles present, numbering 2 in each sex. Sensilium subspherical (Fig. 2), particularly in males.

Male: margin of sensilium clearly separated from proctiger. Pseudotelomere long, with a vestigial articulation, and distinct stiva. Sternite IX hyaline at apex, with short, but non-spiniform bristles. Subsensilial sclerite present (Fig. 2). Carina ("ventral keel") present. Fulcrum, semi-lunar sclerites ("crescent sclerite") and satellite present. Ford's sclerite distinct but relatively undeveloped. Crochet vestigial. Caverna spiculosa clearly visible. Tubus interior straight or slightly arched. Lateral lobe visible with difficulty in the postero-ventral region.

Female: anal stylet present. Hilla very distinct, sometimes protruding into the bulga; one sclerotized or vestigial papilla present. Area cribriformis situated inferodistally. Ductus bursae not coiled.

Etymology: derived from the Greek words, gymnos meaning naked, and mero, meaning thigh or femur, in reference to the greatly reduced setation of femur I.

Type species: Gymnomeropsylla bunomydis n. sp.

\section{GENERIC DisCusSiON}

Only those genera belonging to the Stivaliinae, sensu Mardon (1981), and possessing a distinct stiva are discussed and compared with the new genus. These genera, all of which are fully referenced in Mardon (1981), are (in alphabetical order):

- Afristivalius Traub, 1980: the distribution of members of this genus is exclusively afrotropical; however, this is not a decisive argument; morphologically separated by the more abundant setae on femur I and on the distal arm of sternite IX of males.

- Gryphopsylla Traub, 1957: phallosome well separated; setation of femur I abundant and distal arm of sternite IX in males with many spiniform bristles.

- Lentistivalius Traub, 1972: closely related to the new genus but femur I and sternite IX as above.

- Medwayella Traub, 1972: male telomere generally thick with a stiva that is often vestigial; sternite IX with distal arm very different - dorsal apex with a distinct lateral flap and several ventral spiniform bristles; femur I with at least five bristles.

- Metastivalius Holland, 1969: cephalic setation generally composed of stout bristles ( $M$. lasiurus, the only species known to have "normal" setation, has very different genitalia); sternite IX with some stout spines or bristles and lacking a hyaline apex. Femur I with very variable setation of 3-10 setae depending on species. - Stivalius Jordan \& Rothschild, 1922: differs with respect to the setation of femur I; also, the distal arm of sternite IX has paired apico-dorsal lobes and a spiniform apico-ventral lobe.

- Striopsylla Holland, 1969: immediately separable by the angular shape of the head and by the striated cuticle.

\section{GYMNOMEROPSYLLA BUNOMYDIS \\ Beaucournu \& Durden, N. SP.}

Material examined

Holotype male, on Bunomys chrysocomus (Hoffmann, 1887) (Rodentia: Muridae: Murinae), Indonesia, Central Sulawesi (Sulawesi Tengah), near Morawali, Gunung


(slide no. B 95397); five paratype males, same host, locality and date, except for one male collected on 5 or 6 March 1980 and labelled as B 95394; one paratype male on Maxomys wattsi Musser, 1991 (Rodentia: Muridae: Murinae), same locality but collected on 5 or 6 March 1980 (B 95392); one allotype female on B. chrysocomus, same locality but collected on 12 March 1980 (B 95390). All specimens collected by C.H.S. Watts.

Etymology: specific epithet derived from the host genus, Bunomys Thomas, 1910.

Deposition of types: holotype male, allotype female and four paratype males deposited in the U.S. National Museum of Natural History (USNMNH) (Smithsonian Institution), Washington, DC. One paratype male deposited in the Natural History Museum, London. One paratype male in the collections of each of the authors, ultimately to be deposited in the USNMNH, and Laboratoire d'Entomologie du Muséum national d'bistoire naturelle de Paris (MNHN), respectively.

\section{DESCRIPTION}

Head (Fig. 1) rounded. Four irregular rows of bristles in preantennal region; only the frontal row is well aligned and consists of six bristles; none of the bristles have a tendency to be spiniform. Eye crescent-shaped, partly bordering antennal fossa, positioned above the apex of coxa I. Labial palp with five articles attaining or, more often, exceeding 3/4 the length of the coxa. Antennae lacking long bristles in both sexes, those of the pedicel extending as far as the $3^{\text {rd }}$ segment of the antennal club. Post-antennal region with about 15 bristles, the posterior row having five.

Thorax. Pronotum (Fig. 1) longer dorsally than the spines of the ctenidium, with two rows of bristles, each with five (or six) and six bristles, respectively. Ctenidium with 23-24 spines in males, and 22 in the single 


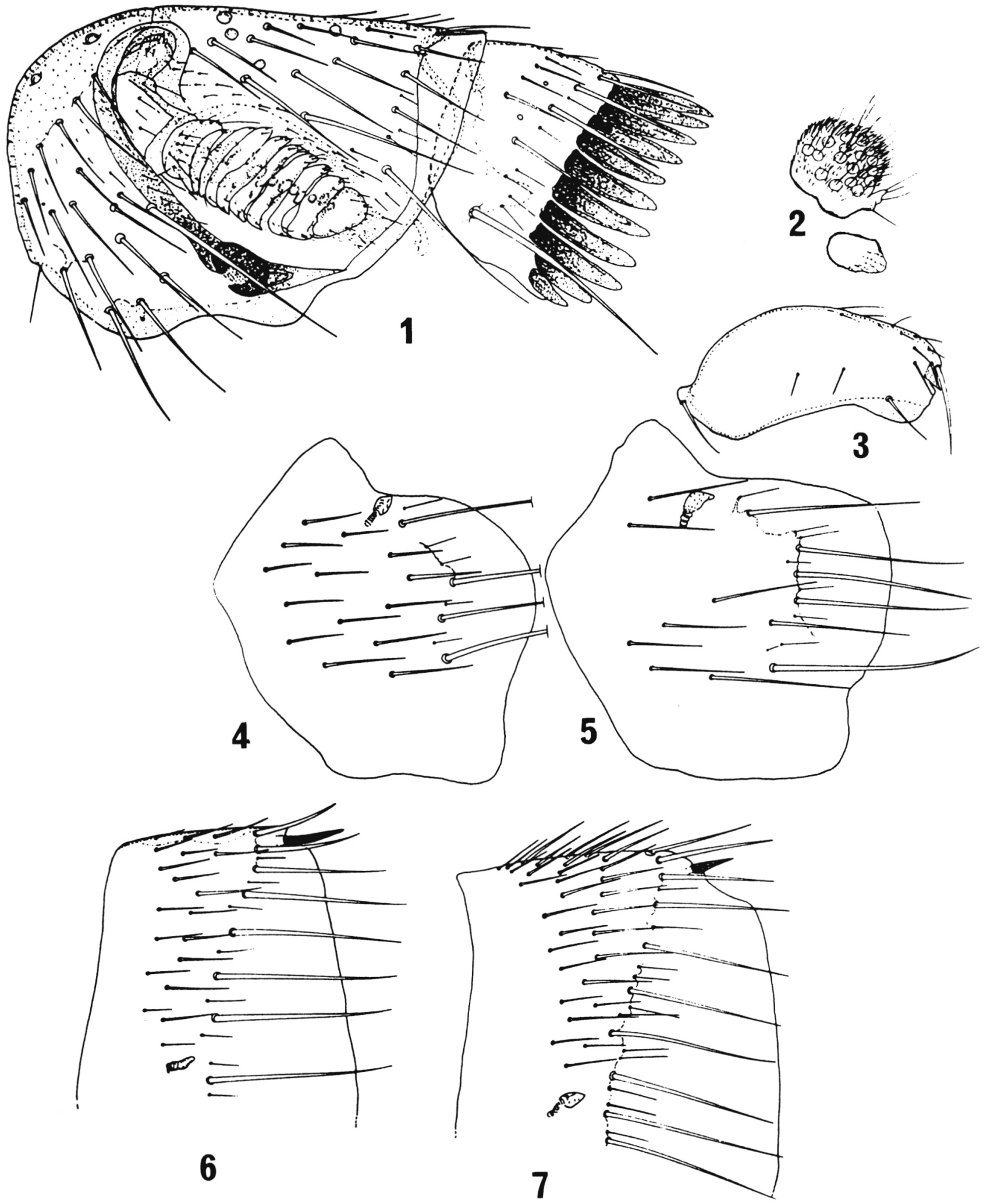

Figs 1-7. - Gymnomeropsylla Durden \& Beaucournu, n. gen. 1: G. bunomydis Beaucournu \& Durden, n. sp., head and pronotum (holotype male); 2: G. bunomydis, sensilium and subsensilial sclerite (in situ) (holotype male); 3: G. bunomydis, femur I (holotype male); 4: G. bunomydis, metepimeron (allotype female); 5: G. margaretamydis Durden \& Beaucournu, n. sp., metepimeron (allotype female); 6: G. bunomydis, tergite II (holotype male); 7: G. margaretamydis, tergite II (paratype male). 
female; the inferior spine is always very short. Procoxa subrectangular, wider posteriorly and with an anteroventral projection. Coxa I with more than 50 fine bristles laterally. The ratio of length (measured from the apex of the insertion of the trochanter)/width is, on average, 1.99 in males (range, 1.85-2.12) and 2.04 in the single female. Femur I (Fig. 3) with 0-3 lateral bristles. Tarsus: segment sizes: $1>2>3>4$; the $1^{\text {st }}$ is the same length as the fifth; these have five pairs of classical bristles: $1^{\text {st }}$ pair situated on the plantar surface at the same level as the $2^{\text {nd }} ; 3^{\text {rd }}$ pair slightly displaced towards the middle of the plantar surface; four apical spiniform bristles present in males (two in the female); tarsal claws not distinctive. Mesonotum with six irregular rows of bristles, usually with three bristles in each of the first five rows; four long bristles in the posterior row; one (or two) robust, sclerotized pseudosetae situated dorsally. Femur II: without a lateral bristle. Four (sometimes five) apical, spiniform plantar bristles in males (two in the female). Metanotum: 25-30 bristles in four irregular rows, the last being submarginal and having five-six bristles. Pleural arch well developed. Metepimeron (Fig. 4) with about 12-14 bristles and four long submarginal bristles; spiracle almost diamondshaped. Coxa with an area of about 25 bristles inferomarginally. Femur lacking lateral bristles. Tibia: eight notches with lateral bristles, becoming marginal between notches 5 and 6 (one bristle), 6 and 7 (two bristles), and 7 and 8 (one bristle); longest apical bristle extending halfway towards the $1^{\text {st }}$ tarsal article. Tarsus at least as long as the tibia, its posterior margin having a series of short, thick, joined bristles. Only two apical spiniform plantar bristles are present on the terminal tarsal article in both sexes.

Abdomen (non-genital segments): Tergite I with five rows of bristles (about 25 bristles in total) with seven large bristles in the submarginal row. Tergite II (Fig. 6): about 25 bristles in four rows (the $1^{\text {st }}$ row vestigial, the last with seven long bristles, one of which is below the spiracle); one relatively long, sclerotized spinelet; spiracle longer than wide. Tergites III-VI each with three rows of bristles, the last row with sevennine long, classical bristles, of which, one or two are below the spiracle. One spinelet on each of tergites III and IV, and occasionally also on tergite V. In the unique female, spinelets are present on tergites II-VI. Tergite VII: antesensilial bristles: the upper, about half the length of the lower, in males; about $4 / 5$ of that length in the female. Sternite II: 0-4 microbristles laterally; three short marginals, and one long, curved distal seta. Sternites III-VII: each with 9-14 lateral bristles and four robust submarginals (five in the female).

Abdomen (genital segments and phallosome of male). Sternite VIII oblong, regular in outline, with about 35 bristles, none of them spiniform or subspiniform. Tergite IX (Fig. 8): dorsal lobe of basimere squarish, rejoining the ventral lobe in a concave line; ventral lobe with two classical bristles, the upper measuring 3/5 the length of the lower. Pseudotelomere long, narrow, digitiform and terminating in a distinct stiva. A dozen short bristles, on average, are present along the ventral margin of the median lobe including five larger bristles in the apical third. Sternite IX (Fig. 8) characterized by its shape, its lack of spiniform bristles, and an enlarged hyaline apex postero-ventrally. Phallosome (Fig. 9) with distinctive Ford's sclerite (alpha-portion) having a dorsal triangular section and a subrectangular and acuminate apex. Tubus interior subrectilinear, with an apicoanterior "beak". Some micro-pseudosetae are visible at high magnification on a membrane that resembles a palliolum ("hood of aedeagus", of Traub, 1972a). The drawn part of this region could perhaps be an artifact from the superposition of two organs.

Abdomen (female genital segments, spermatheca and ducti). Sternite VII (Fig. 10) lacking a major concavity. Tergite VIII as in figure 10. Sternite VIII, narrow, slightly pigmented, with a single apical microbristle. Proctiger (Fig. 10): dorsal valve with anal stylet inserted $2 / 3$ along its margin; ventral valve extending dorso-apically in the form of a spiniform lobe. Ventral margin as in figure 10. Spermatheca (Fig. 11): bulga with thick wall, longer than billa which has a robust, pigmented papilla. There is no protrusion of the billa into the bulga. Ductus bursae (Fig. 11) short, not coiled; only the base of the ductus communis (here, ductus spermathecae) is discernable and is surrounded by a tube that is undoubtedly glandular, with a series of annulations at this level. There is no trace of annular sclerifications ("sclerotic rings" of Smit, 1958) in the single specimen.

Dimensions (slide-mounted insects). Males, average $3.7 \mathrm{~mm}$ (holotype 3.7, range 3.6-3.9). Female (allotype) $4.6 \mathrm{~mm}$.

\section{GYMNOMEROPSYLLA MARGARETAMYDIS DURDEN \& BEAUCOURNU, N. SP.}

Material examined

Holotype male on Margaretamys parvus Musser, 1981 (Rodentia: Muridae: Murinae), Indonesia, Central Sulawesi (Sulawesi Tengah), Gunung Nokilalaki, 2,255 m (1 ${ }^{\circ} 16^{\prime}$ S; $120^{\circ} 10^{\prime} \mathrm{E}$ ), 26 March 1975 (slide no. B 94850); two paratype males, same host and location but 21 March 1975 (B 94848) and 1 April 1975 (B 94854); allotype female, same host and location as holotype but 2,225 $\mathrm{m}$ and 30 March 1975 (B 94853); one female paratype, same host and location as holotype but 25 March 1975 (B 94849). All specimens collected by Guy G. Musser. 


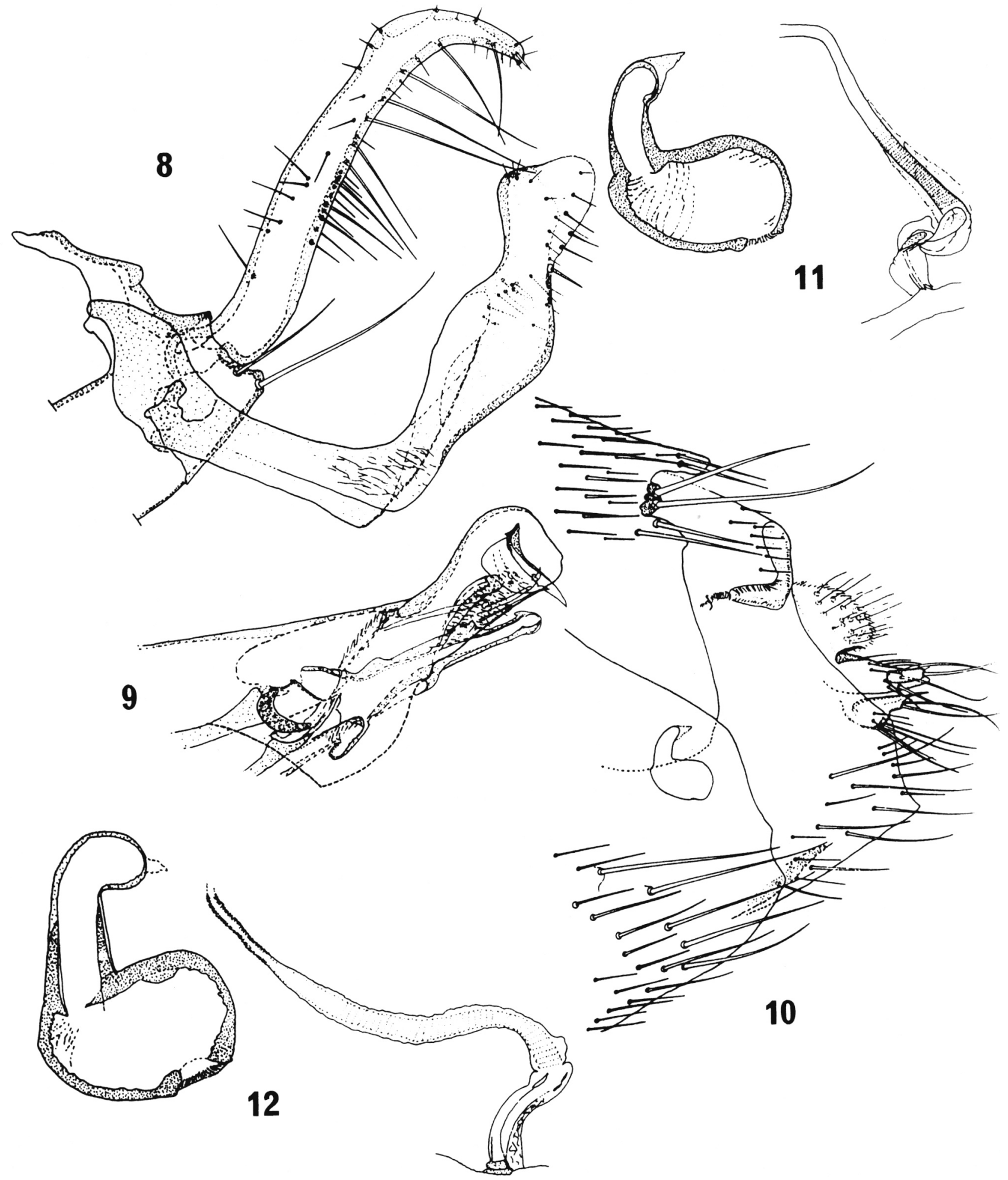

Figs 8-12. - Gymnomeropsylla Durden \& Beaucournu, n. gen. 8: G. bunomydis Beaucournu \& Durden, n. sp., segment IX (holotype male); 9: G. bunomydis, phallosome (paratype male); 10: G. bunomydis, segments VII, VIII and IX (allotype female); 11: G. bunomydis, spermatheca and ducti (allotype female); 12: G. margaretamydis Durden \& Beaucournu, n. sp., spermatheca and ducti (allotype female). 
Etymology: specific epithet derived from the host genus, Margaretamys Musser, 1981.

Deposition of types: holotype male, allotype female and one paratype male deposited in the USNMNH, Washington DC. Two paratypes (one male, one female; respectively, B 94848 and B 94849) in the collection of J.C. Beaucournu, ultimately to be deposited in the MNHN, Paris.

\section{DESCRIPTION}

Head as in G. bunomydis; labial palp at least $4 / 5$ the length of coxa I or extending to its apex. One of the males has a distinct tentorial arch which is accidental or vestigial.

Thorax. Pronotum: one vestigial row of small bristles sometimes present; the two following rows consist of 5-7 bristles each, with most inserted at a $45^{\circ}$ angle to the dorsal border. Ctenidium with 24 spines in males and 22 in females, with the lowest spine always small; the dorsal spines are slightly longer (males), or subequal in length to the dorsal border of the prothorax (females). Coxa I has 40-45 bristles on its lateral surface; its length/width ratio is 1.82 in males and 1.88 in females. Femur I with one (most often) to three (on one side only) bristles. Plantar setation as in the preceding species; this is also true for legs II and III. Mesonotum: numerous erect bristles forming the shape of a crescent anteriorly to posteriorly, continuing as very irregular dorsal rows (five rows, the first vestigial): 3035 bristles plus five or six in the distal row; two peudosetae dorsally (one male also has a unilateral spinelet). Metanotum: with erect dorsal setae; 24-26 bristles in four rows, the last row with 5-6 long bristles. Metepimeron (Fig. 5) with fewer bristles than in G. bunomydis; spiracle relatively large. Coxa with only about 15 bristles in the infero-internal region. Tibia with seven notches and one supernumerary bristle between notches 3 and 4,4 and 5, 5 and 6 , and 6 and 7. Other thoracic characters are as in the preceding species.

Abdomen (non genital segments). Immediately distinguishable by the numerous erect bristles present on tergites I-VII (Fig. 7 and 15) which continue to the thoracic segments. One spinelet present on each of segments II-IV (one specimen also with one on segment V). Tergite I with 20-30 bristles (more numerous in females), plus a distal row of 5-7 long bristles. Tergite II with 20-28 bristles in three rows, plus a distal row of 9-11 bristles, two of which are generally below the spiracle. Tergites III-VI each with a distal row of 11 or 12 long bristles, two or three of which are below the spiracle. Tergite VII with two antesensilial bristles in the same size ratio as reported for G. bunomydis. Sternite II: lateral setation very variable with 112 small bristles; $3-4$ marginal bristles, the posterior one being more stout and curved. Sternites III-VII each with
8-18 small bristles on average and a submarginal row of four bristles in males, 4-7 in females.

Abdomen (male genital segments and phallosome). Sternite VII more rounded than in G. bunomydis and having fewer bristles (about 25), none of which are modified. Tergite IX (Fig. 13): dorsal lobe of basimere acuminate, connected to the ventral lobe by a distinct $\mathrm{V}$-shaped incision. This lobe has two classic bristles, but the upper is very short. Pseudotelomere slightly more convex dorsally than in G. bunomydis and clearly with fewer bristles medio-ventrally. Sternite IX (Fig. 13) close to that of the preceding species but with a more prominent hyaline lobe, directed dorsally and with some postero-ventral bristles slightly thicker. Phallosome (Fig. 14) distinguished by Ford's sclerite lacking a dorsal protuberance, a more curved tubus interior, and lacking an apical "beak". The palliolum of the aedeagus is angled in this species, not rectilinear.

Abdomen (female genital segments, spermatheca and $d u c t i)$. Sternite VII (Fig. 15) entirely convex, except in the ventral region. Tergite VIII as in figure 15. Sternite VIII wider than in the preceding species with several microbristles apically. Proctiger (Fig. 15): dorsal valve with anal stylet inserted apically and about as long as $2 / 3$ the length of the valve; ventral valve similar to that of $G$. bunomydis (appearing the same in the smallest female examples examined). Spermatheca (Fig. 12): bulga thick-walled, more spherical than in the congeneric species; billa about equal in length to the bulga, rectilinear except at the apex, and protruding partly into the bulga, with a non-sclerotized papilla that is discernably slightly enlarged. Ductus bursae (Fig. 12) arched, relatively short; ductus communis wide, ringed, and having a short section with 20-25 sclerifications.

Dimensions (slide-mounted insects): Males, average $3.6 \mathrm{~mm}$ (holotype 3.6); females, average 4.25 (allotype 4.0).

\section{DISCUSSION}

The genetic separation of the two species of Gymnomeropsylla described here is clear. The geological and biogeographical isolation of Sulawesi was presumably a major factor in the evolution of this undescribed genus on that island whereas differences in altitude, hosts, regional geography and/or habitat within Sulawesi may have provided selection for the evolution of the two new species. Gymnomeropsylla bunomydis and G. margaretamydis are easily separated based on the more abundant setae on the latter species. Also, the morphology of Ford's sclerite in males and the spermatheca of females, are diagnostic characters for each of these species. 


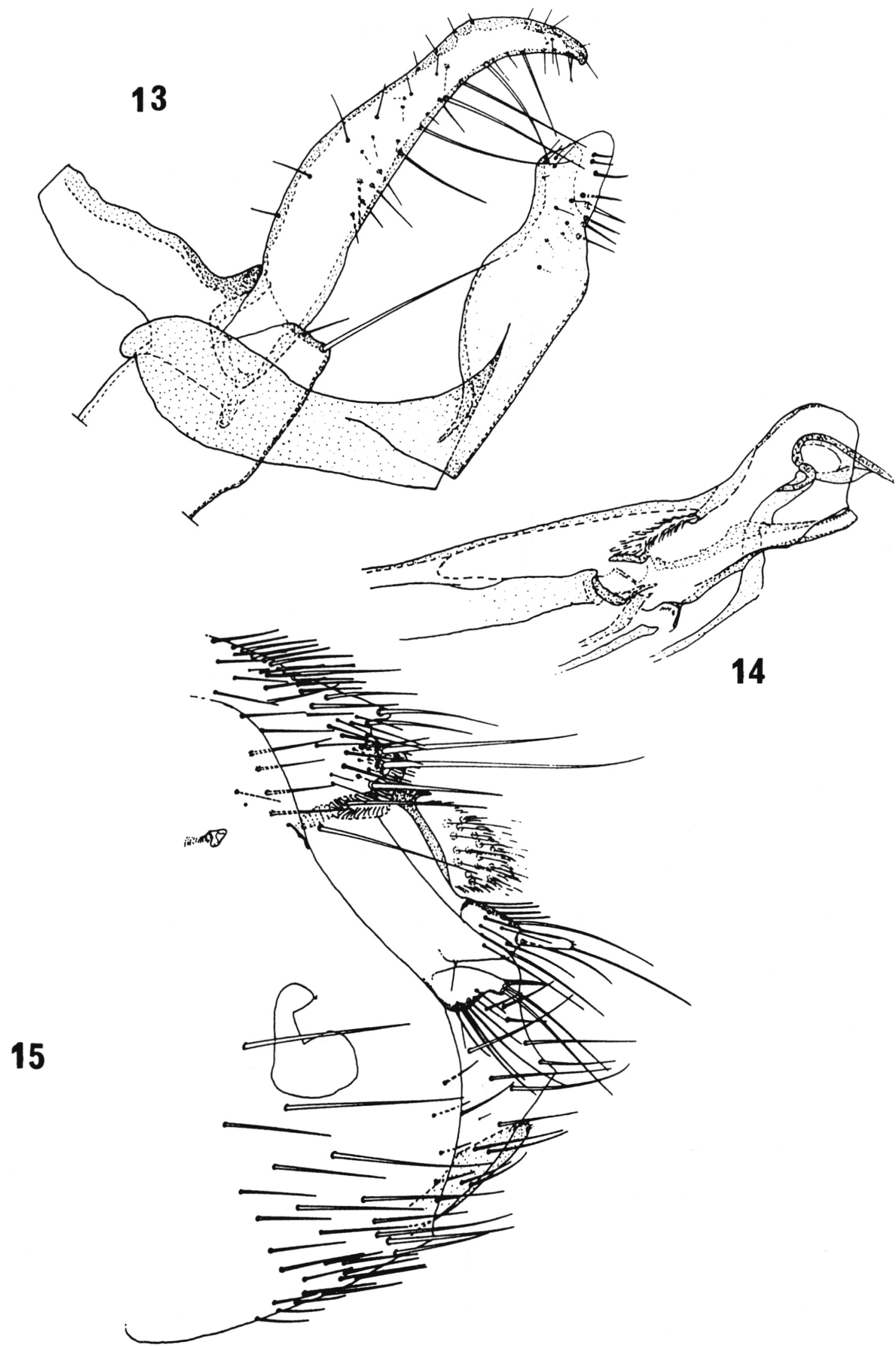

Figs 13-15. - Gymnomeropsylla margaretamydis Durden \& Beaucournu, n. gen., n. sp. 13: segment IX (tergite, holotype male; sternite, paratype male); 14: phallosome (paratype male); 15: segments VII, VIII and IX (composite drawing from allotype and paratype females) 
Both new species were recovered only from mammals that are endemic to Sulawesi. In fact, two of the three host genera, Bunomys and Margaretamys, are also endemic to this island. Representatives of the third host genus, Maxomys, are also found in the Sundaic region (where they are represented by different species) to the west of Sulawesi (Musser, 1991). Gymnomeropsylla bunomydis was collected mainly from the murine rodent $B$. chrysocomus (eight specimens) but also from the murine $M$. wattsi (one specimen). Bunomys chrysocomus occurs throughout Sulawesi from lowland evergreen tropical rainforest to lower montane rainforest (Musser \& Holden, 1991), whereas $M$. watts $i$ is known only from the montane rainforests on Gunung (Mount) Tambusisi in the eastern peninsula of Central Sulawesi (Sulawesi Tengah) (Musser, 1991). However, G. bunomydis was only collected from hosts that were trapped at an elevation of $1,430 \mathrm{~m}$ on this mountain. Gymnomeropsylla margaretamydis was recovered only from the murine $M$. parvus. This murine is only known from lower and upper montane rainforest in Central Sulawesi (Musser \& Holden, 1991). Gymnomeropsylla margaretamydis was collected from this rodent only at elevations of $2,225 \mathrm{~m}$ and 2,255 $\mathrm{m}$ on Gunung Nokilalaki which is situated just south of the base of the northern peninsula of Sulawesi. The existence of this new flea genus on Sulawesi suggests that other undescribed flea taxa also inhabit that island.

\section{ACKNOWLEDGEMENTS}

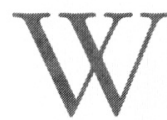

e are grateful to both Christopher H.S. Watts (South Australian Museum, Adelaide) and Guy G. Musser (American Museum of Natural History, New York, USA) (AMNH) for collecting these new fleas during their fieldwork in Sulawesi. Christopher Watts collected specimens during "Operation Drake" which was sponsored by the British Scientific Exploration Club. Guy Musser's fieldwork was funded by the Celebes Fund of the AMNH and by Archbold Expeditions, Inc. Lance Durden was also partly funded by the Celebes Fund of the AMNH and by a Research Excellence Award from Georgia Southern University. We are extremely grateful to the late Robert Traub (formerly of Bethesda, Maryland, USA) for providing access to fleas in his collection and for many stimulating discussions concerning the flea fauna of Sulawesi.

We take advantage of this note to correct a lapsus in the article by Beaucournu \& Durden (2001); there were three species of pygiopsyllids, not two, described from Sulawesi before our article ("Deux Stivalius ... nouveaux d'Indonésie"). We inexplicably omitted from this work Gryphopsylla hetera Lewis \& Jones, 1985.

\section{REFERENCES}

Beaucournu J.C. \& Durden L.A. Deux Stivalius (Siphonaptera - Pygiopsyllidae - Pygiopsyllinae) nouveaux d'Indonésie. Parasite, 2001, 8, 147-153.

Beaucournu J.C., Sountsov V.V., Ly T.V.H. \& Sountsova N.I. Esquisse d'une biogéographie des puces (Insecta, Siphonaptera) du Vietnam. Biogeographica, 2000, 76, 1-20.

Durden L.A. \& Traub R. Zoogeographical implications from rodent ectoparasites in Sulawesi, in: Knight W.J. \& Holloway J.D. (Editors), Insects and the rain forests of South East Asia (Wallacea), Royal Entomological Society, London, 1990, 557-562.

LEKAGUL B. Mammals of Thailand. Kurusapha Ladprao $\left(2^{\text {nd }}\right.$ edition, 1988, Darnsutha Press, LI + 758 p.).

LEwIS R.E. Résumé of the Siphonaptera (Insecta) of the World. Journal of Medical Entomology, 1998, 35, 377-389.

MARDON D.K. An illustrated catalogue of the Rothschild collection of fleas (Siphonaptera) in the British Museum (Natural History). Volume VI: Pygiopsyllidae. British Museum (Natural History), London, 1981, 298 p.

Musser G.G. Sulawesi rodents: descriptions of new species of Bunomys and Maxomys (Muridae, Murinae). American Museum Novitates, 1991, 3001, 1-40.

Musser G.G. \& Holden M.E. Sulawesi rodents (Muridae: Murinae): morphological and geographical boundaries of species in the Rattus hoffmanni group and a new species from Pulau Peleng. Bulletin of the American Museum of Natural History, 1991, 206, 322-413.

SMit F.G.A.M. The African species of Stivalius, a genus of Siphonaptera. Bulletin of the British Museum (Natural History), Entomology, 1958, 7, 41-76.

SMiт F.G.A.M. An illustrated catalogue of the Rothschild collection of fleas (Siphonaptera) in the British Museum (Natural History). Volume VII: Malacopsylloidea (Malacopsyllidae and Rhopalopsyllidae). Oxford University Press, 1987, 380 p.

Traub R. The Gunung Benom Expedition 1967. 11. Notes on zoogeography, convergent evoloution and taxonomy of fleas (Siphonaptera) based on collections from Gunung Benom and elsewhere in South-east Asia. I. New taxa (Pygiopsyllidae, Pygiopsyllinae). Bulletin of the British Museum (Natural History), Zoology, 1972a, 23, 201-305 (+ 58 plates)

Traub R. The Gunung Benom Expedition 1967. 13. Notes on zoogeography, convergent evolution and taxonomy of fleas (Siphonaptera) based on collections from Gunung Benom and elsewhere in South-east Asia. III. Zoogeography. Bulletin of the British Museum (Natural History), Zoology, 1972b, 23, 391-450.

Traub R., Rothschild M. \& Haddow J.F. The Rothschild collection of fleas. The Ceratophyllidae: key to the genera and host relationships with notes on their evolution, zoogeography and medical importance. Academic Press, London and Cambridge University Press, 1983, 288 p. + 205 figures, 90 plates \& 151 maps.

Reçu le 26 février 2002 Accepté le 22 avril 2002 